\title{
Forum
}

\section{Effects of Grazing Pressure on Efficiency of Grazing on North American Great Plains Rangelands}

\author{
A. J. Smart, ${ }^{1}$ J. D. Derner, ${ }^{2}$ J. R. Hendrickson, ${ }^{3}$ R. L. Gillen, ${ }^{4}$ B. H. Dunn, ${ }^{5}$ E. M. Mousel, ${ }^{6}$ \\ P. S. Johnson, ${ }^{7}$ R. N. Gates, ${ }^{8}$ K. K. Sedivec, ${ }^{9}$ K. R. Harmoney, ${ }^{10}$ J. D. Volesky, ${ }^{11}$ and K. C. Olson ${ }^{8}$ \\ Authors are ${ }^{1}$ Associate Professor and ${ }^{6}$ Assistant Professor, Department of Animal and Range Sciences, South Dakota State University, Brookings, SD \\ 57007, USA ${ }^{2}$ Rangeland Scientist, US Department of Agriculture-Agricultural Research Service (USDA-ARS) High Plains Grasslands Research Station, \\ Cheyenne, WY 82009, USA; ${ }^{3}$ Rangeland Scientist, USDA-ARS Northern Great Plains Research Laboratory, Mandan, ND 58554, USA; ${ }^{4}$ Head and \\ Professor and ${ }^{10}$ Associate Professor, Western Kansas Agricultural Research Center, Kansas State University, Hays, KS 67601, USA; ${ }^{5}$ Executive Director \\ and Endowed Chair of the King Ranch Institute for Ranch Management, Texas A\&M University-Kingsville, Kingsville, TX 78363, USA; ${ }^{7}$ Professor and \\ ${ }^{8}$ Associate Professors, Department of Animal and Range Sciences, South Dakota State University, West River Agricultural Center, Rapid City, SD 57702, \\ USA; ${ }^{9}$ Associate Professor, School of Natural Resource Sciences, North Dakota State University, Fargo, ND 58108, USA; and ${ }^{11}$ Professor, Department of \\ Agronomy and Horticulture, West Central Research and Extension Center, University of Nebraska-Lincoln, North Platte, NE 69101, USA.
}

\begin{abstract}
Comparisons of stocking rates across sites can be facilitated by calculating grazing pressure. We used peak standing crop and stocking rates from six studies in the North American Great Plains (Cheyenne, Wyoming; Cottonwood, South Dakota; Hays, Kansas; Nunn, Colorado; Streeter, North Dakota; and Woodward, Oklahoma) to calculate a grazing pressure index and develop relationships for harvest efficiency, utilization, grazing efficiency, and animal performance and production. Average grazing pressures for heavy, moderate, and light stocking across the study sites were 40, 24, and 14 animal unit days $\cdot \mathrm{Mg}^{-1}$, respectively. These grazing pressures resulted in average harvest efficiency values of 38\%, 24\%, and 14\% and grazing efficiencies of $61 \%$, $49 \%$, and $39 \%$ for heavy, moderate, and light stocking rates, respectively. Utilization increased quadratically as grazing pressure index increased, whereas grazing and harvest efficiencies exhibited a linear increase with grazing pressure. The latter indicates that nonlivestock forage losses (e.g., weathering, senescence, wildlife, insects) were disproportional across stocking rates. Average daily gain of livestock decreased linearly as grazing pressure index increased across study sites. Prediction equations reaffirm assumptions of $50 \%$ grazing efficiency and $25 \%$ harvest efficiency associated with moderate stocking. Novel here, however, is that harvest and grazing efficiencies increased at high grazing pressures and decreased at low grazing pressures. Use of grazing pressure index to "standardize" stocking rates across rangeland ecosystems in the North American Great Plains should improve communication among scientists, resource managers, and the public, and thus better achieve both production and conservation goals on these lands.
\end{abstract}

\section{Resumen}

La estimación de la presión de pastoreo puede facilitar la comparación de carga animal entre sitios. Se utilizaron datos de máxima biomasa aérea en pie y carga animal de seis ensayos realizados en las Planicies Centrales de América del Norte (Cheyenne, WY; Cottonwood, SD; Hays, KS; Nunn, CO; Streeter, ND; y Woodward, OK) para calibrar un índice de presión de pastoreo y desarrollar relaciones de eficiencia de cosecha, utilización, eficiencia de pastoreo, y performance y producción animal. Las presiones de pastoreo promedio para cargas altas, moderadas, y leves en todos los sitios fueron de $40,24, \mathrm{y} 14 \mathrm{UAD} \cdot \mathrm{Mg}^{-1}$, respectivamente. Estas presiones de pastoreo resultaron en valores de eficiencia de cosecha promedio de 38, 24, y 14\% y eficiencias de pastoreo de 61, 49, y 39\% para cargas altas, moderadas, y leves, respectivamente. Aumentos en el índice de presión de pastoreo estuvieron asociados a un incremento cuadrático de la utilización, mientras que las eficiencias de pastoreo y de cosecha exhibieron un incremento lineal con el aumento de presión de pastoreo. Esto último indica que las pérdidas de forraje no debidas al ganado (ej., maduración, senescencia, fauna, insectos) fue desproporcional para las diferentes cargas animales. La ganancia de peso promedio del ganado decreció de modo lineal a medida que aumentó el índice de presión de pastoreo en los diferentes sitios. Las ecuaciones predictivas reafirman los supuestos del $50 \%$ de eficiencia de pastoreo y el $25 \%$ de eficiencia de cosecha asociadas con el pastoreo moderado. Lo nuevo de este análisis es que las eficiencias de cosecha y pastoreo aumentaron con cargas altas y disminuyeron con cargas leves. El uso de índices de presión de pastoreo para "estandarizar" la carga animal en todos los ecosistemas de pastizales naturales de las Planicies Centrales de América del Norte debería facilitar la comunicación entre investigadores, técnicos, y el público para mejorar el logro de las metas de producción y conservación de estas tierras.

Key Words: animal performance, forage disappearance, grazing efficiency, harvest efficiency, herbage intake, stocking rate, utilization

Correspondence: Alexander J. Smart, Dept of Animal and Range Sciences, South Dakota State University, Box 2170, Brookings, SD 57007, USA. Email: alexander.smart@sdstate.edu 


\section{INTRODUCTION}

Selecting the appropriate stocking rate is the most important grazing management decision a producer can make (Holechek et al. 2004). Observations made in the late 19th and early 20th centuries demonstrated that overgrazing caused significant vegetation deterioration on North American rangelands (Parker 1954). Relationships between stocking rate and productivity of vegetation and livestock initially were determined for northern mixed-grass prairie near Mandan, North Dakota, in the mid-1910s (Riewe 1961). Numerous stocking rate studies were initiated in the 1940s and 1950s throughout North America (Harlan 1958; Riewe 1961; Van Poollen and Lacey 1979). These individual studies laid the foundation for our understanding of how the range succession model (Dyksterhuis 1949) worked in different North American Great Plains rangeland ecosystems. In the 1950s and 1960s, researchers began to combine livestock and vegetation responses with applications of economics across stocking rates. For example, Klipple and Bement (1961) analyzed three long-term stocking rate studies to determine the economic feasibility of light stocking to improve range condition. Riewe (1961) reviewed data from nine studies and reported relationships between stocking rate, gain per animal, and gain per acre for each location separately. Harlan (1958) combined findings from 10 studies and explained animal gain per head as a double exponential function of stocking rate. However, the procedure used to standardize stocking rates across studies was not explicitly reported. Hart (1972) described the limitations of Harlan's (1958) approach and proposed calculating forage allowance (forage yield divided by number of animal days per unit area) as a way to standardize stocking rate. Hart (1972) also calculated grazing pressure (inverse of forage allowance) and showed mathematically that the relationship between average daily gain (ADG) and forage allowance was nonlinear, and the relationship between ADG and grazing pressure was linear. Sollenberger et al. (2005) also suggested that forage allowance would be a useful method to standardize stocking rate studies. The rationale behind using forage allowance or grazing pressure was based on previous findings that animal weight gain can be limited by forage supply (Conniffe et al. 1970). A review of the literature (Allison 1985) and prediction equations by Redmon et al. (1995) and Poppi (1996) support the concept that forage availability limits intake and thus should limit animal weight gain.
Grazing efficiency (the proportion of forage consumed by livestock compared to the total that disappears due to all other activities) increases as grazing pressure increases (Combellas and Hodgson 1979; Stuth et al. 1981; Allison et al. 1982; Penning et al. 1991; Mazzanti and Lemaire 1994; Nakatsuji et al. 2006). We propose that a grazing pressure index (GPI) as defined by the Society for Range Management (SRM 1998) as an "animal to forage relationship measured in terms of animal units per unit of weight of forage over a period of time" would be useful to standardize stocking rate studies across a wide geographic region to better describe the relationships between GPI, utilization, grazing efficiency, and harvest efficiency (the proportion of forage consumed by livestock compared to the forage produced). Most grazing studies measure standing crop biomass and stocking rate, which can then be used to calculate GPI (animal unit days [AUD] $\cdot \mathrm{Mg}^{-1}$; AUD divided by forage weight in megagrams; where one AU equals one mature cow of approximately $454 \mathrm{~kg}$, either dry or with calf up to $6 \mathrm{mo}$ of age, or their equivalent consuming about $12 \mathrm{~kg}$ of forage on an oven-dry basis). A greater understanding of the influence of GPI on efficiency of grazing across rangeland ecosystems in the North American Great Plains would aid decision making in these grazing-resistant ecosystems (Milchunas et al. 1988). In addition, knowledge of these relationships would assist in contemporary management regarding both livestock production and conservation goals (Derner et al. 2009).

Objectives of this study were to 1) quantify GPI, utilization, and harvest and grazing efficiencies at heavy, moderate, and light stocking rates; and 2) evaluate the relationships between GPI and utilization, harvest and grazing efficiencies, and animal performance and production across six studies conducted in the North American Great Plains. We hypothesized that vegetation and animal responses would exhibit linear relationships with GPI.

\section{MATERIALS AND METHODS}

\section{Stocking Rate Study Descriptions and Calculations}

Published and unpublished data from six studies conducted in the North American Great Plains (Table 1) were used in this study. The six studies provided the necessary data (peak standing crop biomass, residual biomass, and stocking rate) to calculate GPI and utilization. However, data on forage disappearance due to livestock intake needed to calculate harvest

Table 1. Site, latitude/longitude, vegetation type, ecological site, annual precipitation, study period, and references of stocking rate studies in the North American Great Plains.

\begin{tabular}{|c|c|c|c|c|c|c|}
\hline Site & Lat, long & Vegetation type & Ecological site & $\begin{array}{c}\text { Annual } \\
\text { precipitation (mm) }\end{array}$ & Study period & References \\
\hline Cheyenne, WY & $41^{\circ} 11^{\prime} \mathrm{N}, 104^{\circ} 53^{\prime} \mathrm{W}$ & Northern mixed-grass prairie & Loamy & 381 & $2004-2007$ & $\begin{array}{l}\text { Hart et al. (1988); Derner and } \\
\text { Hart (2007) }\end{array}$ \\
\hline Cottonwood, SD & $43^{\circ} 94^{\prime} \mathrm{N}, 101^{\circ} 85^{\prime} \mathrm{W}$ & Northern mixed-grass prairie & Clayey & 407 & $1945-1955$ & Smart et al. (2007) \\
\hline Hays, KS & $38^{\circ} 52^{\prime} \mathrm{N}, 99^{\circ} 19^{\prime} \mathrm{W}$ & Central mixed-grass prairie & Loamy upland & 582 & $1957-1966$ & Launchbaugh (1967) \\
\hline Nunn, CO & $40^{\circ} 49^{\prime} \mathrm{N}, 107^{\circ} 46^{\prime} \mathrm{W}$ & Shortgrass steppe & Loamy & 341 & 1991-2006 & Hart and Ashby (1998) \\
\hline Streeter, ND & $46^{\circ} 46^{\prime} \mathrm{N}, 99^{\circ} 28^{\prime} \mathrm{W}$ & Northern mixed-grass prairie & Loamy & 454 & $1991-2005$ & Patton et al. (2007) \\
\hline Woodward, OK & $36^{\circ} 27^{\prime} \mathrm{N}, 99^{\circ} 23^{\prime} \mathrm{W}$ & Sand sagebrush-mixed prairie & Sand hills & 576 & $1958-1961$ & Gillen and Sims $(2002,2004)$ \\
\hline
\end{tabular}




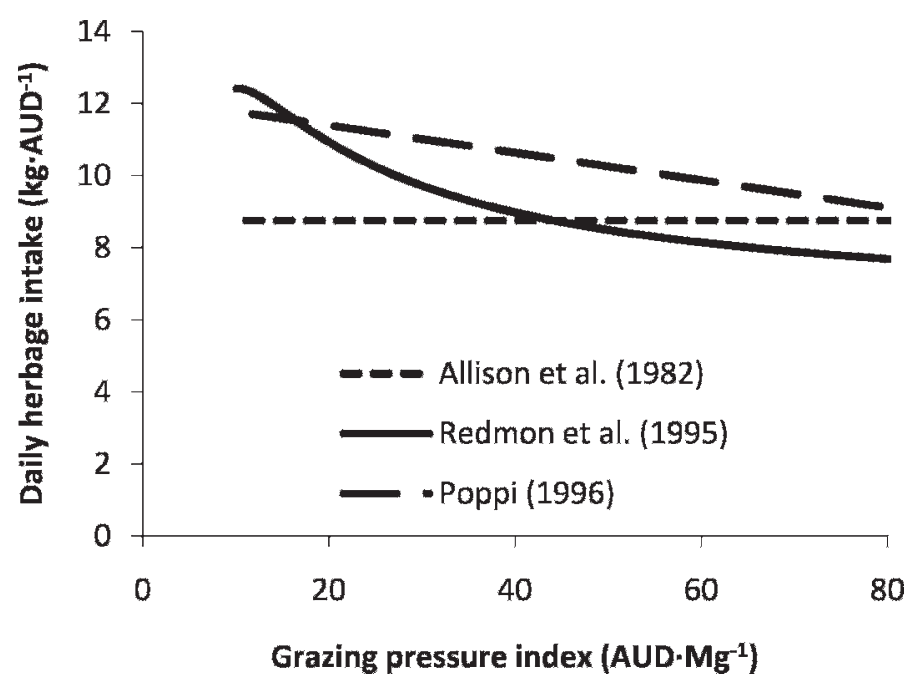

Figure 1. Relationship between daily herbage intake and grazing 2pressure index (GPI). Intake for the Allison et al. (1982) equation assumes intake is a constant $8.75 \mathrm{~kg} \cdot$ animal unit day $[A U D]^{-1}$. Redmon et al. (1995) equation is as follows: intake $=\{1.2989+[120.6 / G P] /$ $\left.4.54-0.0028 \times\left[(220.226 / \mathrm{GP})^{2}\right]\right\} \times 4.54 / 0.95$; where $\mathrm{GPI}=$ grazing pressure index (AUD $\cdot \mathrm{Mg}^{-1}$ ) and is adjusted on a dry matter basis by assuming $5 \%$ ash. Poppi (1996) equation is as follows: intake $=\{103-[710 /(2202.64 / \mathrm{GP})]\} / 100 \times 11.8$; where intake of $11.8 \mathrm{~kg} \cdot \mathrm{AUD}^{-1}$ as defined by SRM (1998) is adjusted for differing levels of GP.

and grazing efficiency were not available. Therefore we estimated daily herbage intake (DHI; $\mathrm{kg}$ of forage intake divided by one AUD) using three methods (Fig. 1) that assumed intake to be either constant or adjusted over different levels of cumulative grazing pressure. The methods were as follows: 1) DHI was assumed to be $8.75 \mathrm{~kg} \cdot \mathrm{AUD}^{-1}(1.9 \%$ of $460 \mathrm{~kg}$ of body weight $\cdot \mathrm{AU}^{-1}$ ) based on the reported average by Allison et al. (1982), where intake was estimated using the fecal excretion:indigestibility ratio technique and fecal output was measured using fecal collection bags; 2) DHI was modeled from intakes of steers grazing winter wheat (Triticum aestivum L.) reported by Redmon et al. (1995), where intake was estimated using the fecal excretion:indigestibility ratio technique and fecal output was estimated using chromic oxide dilution; and 3) DHI was initially set at $11.8 \mathrm{~kg} \cdot \mathrm{AUD}^{-1}$ (SRM 1998) and then modified using an equation reported by Poppi (1996), as discussed in National Research Council (1987).

Grazing pressure index, intake, harvest efficiency, utilization, and grazing efficiency were calculated using the following formulas:

$$
\begin{aligned}
\mathrm{GPI} & =\mathrm{SR} / \mathrm{PSC} \\
\mathrm{I} & =\mathrm{DHI} \cdot \mathrm{SR} \\
\mathrm{HE} & =(\mathrm{I} / \mathrm{PSC}) \cdot 100 \\
\mathrm{U} & =[1-(\mathrm{R} / \mathrm{PSC})] \cdot 100 \\
\mathrm{GE} & =[\mathrm{I} /(\mathrm{PSC}-\mathrm{R})] \cdot 100
\end{aligned}
$$

where GPI = grazing pressure index (AUD divided by weight of forage; $\mathrm{AUD} \cdot \mathrm{Mg}^{-1}$ ), $\mathrm{SR}=$ stocking rate (the relationship between the number of animals and the grazing management unit utilized over a specified time period; AUD $\left.\cdot \mathrm{ha}^{-1}\right), \mathrm{PSC}=$ peak standing crop (the total amount of plant material per unit of space at a given time that it is at its maximum; $\mathrm{kg} \cdot \mathrm{ha}^{-1}$ ), I = herbage intake (amount of forage consumed by animals over a given unit area and period; $\mathrm{kg} \cdot \mathrm{ha}^{-1}$ ), DHI $=$ daily herbage intake $\left(\mathrm{kg} \cdot \mathrm{AUD}^{-1}\right), \mathrm{HE}=$ harvest efficiency (the amount of forage consumed by animals divided by the peak standing crop; \%), $\mathrm{U}=$ utilization (the proportion of current year's forage production that is consumed or destroyed by grazing animals; \%), $\mathrm{R}=$ residual herbage (forage remaining on the land at the end of the grazing period; $\mathrm{kg} \cdot \mathrm{ha}^{-1}$ ), and $\mathrm{GE}=$ grazing efficiency (proportion of forage consumed by grazing animals compared to the total amount that disappears; \%).

\section{Stocking Rate Studies Analyses}

A one-way analysis of variance (ANOVA) was used to test for the main effect of stocking rate for each of the six studies separately using PROC GLM (SAS Institute 2006). Year was considered the replication for experiments that did not have replicates in space (Cottonwood, Hays, Nunn, and Streeter). These studies were analyzed as randomized complete block designs. Experiments that had physical replication (Cheyenne and Woodward) were analyzed using repeated measures with year as the time variable and the study design as a randomized complete block. Residuals of each variable were calculated by treatment and tested for the assumptions of normality using the NORMAL option in PROC UNIVARIATE (SAS Institute 2006). When assumptions of normality were violated, variables were log-transformed (Steel and Torrie 1980) because the standard deviations were proportional to the means. Homogeneity of variances for the variables was compared between treatments using the HOVTEST option in PROC GLM (SAS Institute 2006). When assumptions of homogeneity were violated, variables were log-transformed (Steel and Torrie 1980). Means were separated using the least squares PDIFF option when the Ftest of the main effects were significant at $P<0.05$. Untransformed means are reported.

A two-way ANOVA was used to assess the main effects of study site and stocking rate (heavy, moderate, and light) and their interaction. Year was considered the replication and those studies that had physical replications were averaged within year. These data were analyzed in PROC MIXED (SAS Institute 2006) using a split plot design with study site as the whole plot, year nested within study site as the whole plot error term, treatment and treatment by study site as subplots, and treatment by year nested within study site as the subplot error term. Variables analyzed were GPI, utilization, harvest efficiency, and grazing efficiency. Other variables such as peak standing crop, average daily gain, and animal production were not analyzed because of the confounding effects of study site and animal type. Assumptions of normality and homogeneity of variance were tested and least square means were reported as previously described. Means were assumed to be significantly different at $P \leq 0.05$. 
Table 2. Stocking rate (SR), peak standing crop (PSC), residual biomass (R), utilization (U), average daily gain (ADG), and animal production (AP) from long-term stocking rate studies conducted in the North American Great Plains.

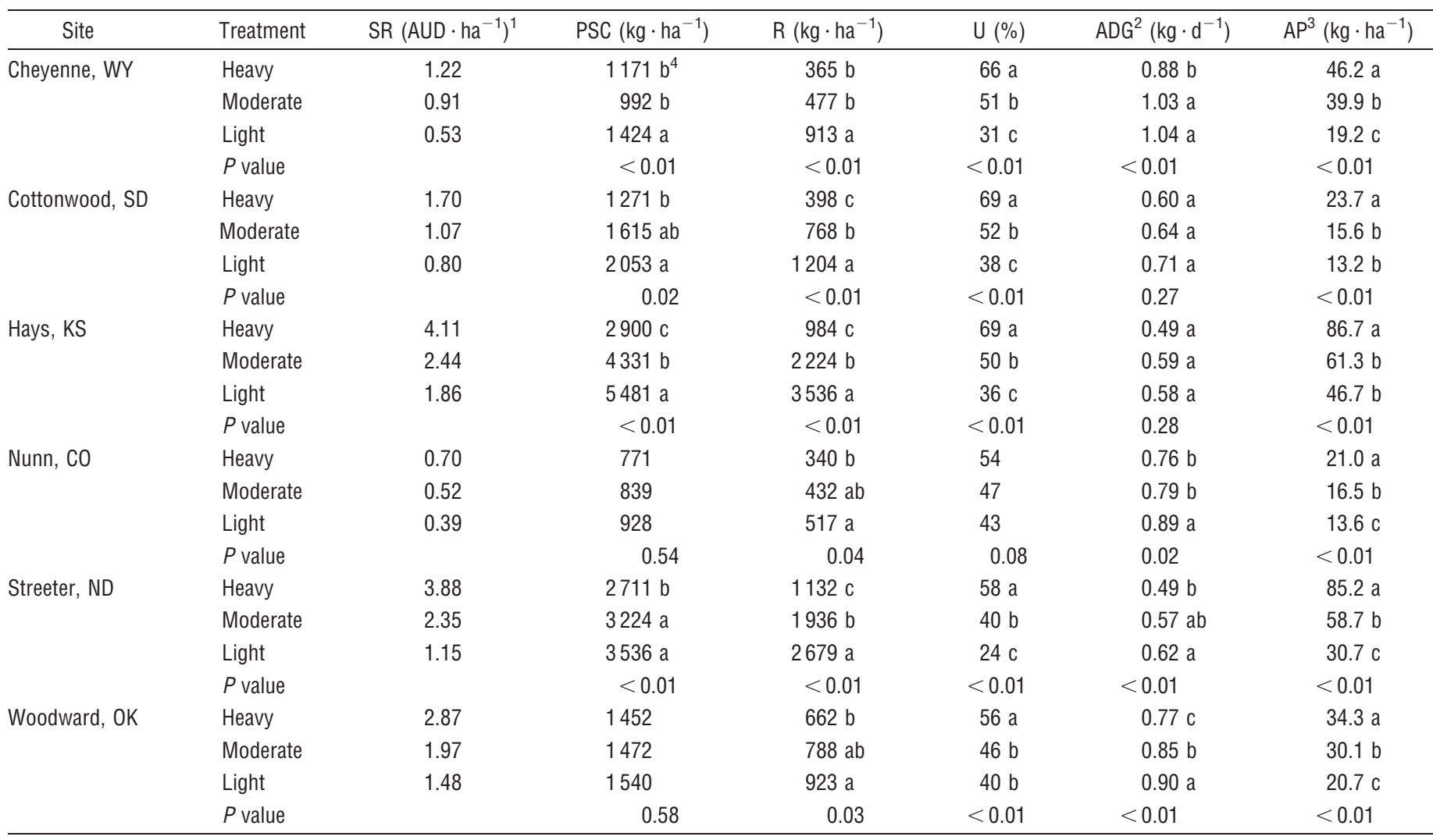

${ }^{1} \mathrm{AUD}$ indicates animal unit days.

${ }^{2} \mathrm{ADG}$ values for Cottonwood and Woodward are for calves, whereas Cheyenne, Hays, Nunn, and Streeter are for yearlings.

${ }^{3} \mathrm{AP}$ values for Cottonwood and Woodward are for calves, whereas Cheyenne, Hays, Mandan, Nunn, and Streeter are for yearlings.

${ }^{4}$ Means within a location and column with different letters are significantly different $(P<0.05)$.

\section{Regression Analyses}

Regression analyses were conducted using GPI as the independent variable and utilization, harvest, or grazing efficiencies as the dependent variable using PROC REG (SAS Institute 2006). Regression analysis of animal performance, as measured by ADG $\left(\mathrm{kg} \cdot \mathrm{d}^{-1}\right)$ and gain $\left(\mathrm{kg} \cdot \mathrm{ha}^{-1}\right)$, using GPI as the independent variable, was performed for the study sites that had yearling cattle only (Cheyenne, Hays, Nunn, and Steeter) in PROC GLM (SAS Institute 2006). Within an individual study site we reduced variation of dependent variables by averaging across years. In order to account for the variation among sites, we used a covariance analysis (Littell et al. 1991) that included separate $y$-intercepts for each site and a pooled slope: $\mathrm{Y}=\mathrm{b}_{0}+\mathrm{b}_{1} \mathrm{x}_{1}+\mathrm{b}_{2} \mathrm{x}_{2}+\mathrm{b}_{3} \mathrm{x}_{3}+\mathrm{b}_{4} \mathrm{GP}$, where $b_{0}$ is the $y$-intercept for Streeter; $b_{1}=$ difference between $y$-intercept for Streeter and Cheyenne; $b_{2}=$ difference between $y$-intercept for Streeter and Hays; $b_{3}=$ difference between y-intercept for Streeter and Nunn; $b_{4}=$ pooled slope across sites; $\mathrm{x}_{1}=1$ for Cheyenne and 0 for other sites; $\mathrm{x}_{2}=1$ for Hays and 0 for other sites; $\mathrm{x}_{3}=1$ for Nunn and 0 for other sites; GPI = grazing pressure index; y-intercept for Cheyenne $=b_{0}+b_{1} ; y$-intercept for Hays $=b_{0}+b_{2} ;$ and $y$ intercept for Nunn $=b_{0}+b_{3}$.

\section{RESULTS}

\section{Stocking Rate Studies}

Summary statistics for the stocking rate treatments at each of the six sites are presented in Table 2. Residual biomass and animal production were different between stocking rates at every site. At most sites, peak standing crop biomass, utilization, and ADG were different between stocking rates.

There was a significant site by stocking rate interaction for GPI and utilization; and for harvest efficiency calculated using each of the three intake equations, but not for grazing efficiency, regardless of intake calculation (Table 3). The Woodward site had greater GPI than the other sites at all three stocking rates (Fig. 2A). Grazing pressure index was similar at the five other sites (Cheyenne, Cottonwood, Hays, Nunn, and Streeter) for the light stocking rate. This, however, did not extend to the moderate and heavy stocking rates at these sites (Fig. 2A). Utilization was similar among sites at the moderate stocking rate, but varied at the heavy and light stocking rates (Fig. 2B). Grazing efficiency estimates did not differ by site and stocking rate regardless of the method used to estimate daily herbage intake (Figs. 3A-3C). However, harvest efficiency was greater at the Woodward site at heavy and light 
Table 3. $P$ values of the main effects and interaction of stocking rate and site for grazing pressure index, utilization, grazing efficiency, and harvest efficiency based on three equations ${ }^{1}$ after Allison et al. (1982), Redmon et al. (1995), and Poppi (1996).

\begin{tabular}{|c|c|c|c|}
\hline Variable & Site & Stocking rate & Site $\cdot$ stocking rate \\
\hline & \multicolumn{3}{|c|}{--10 } \\
\hline Grazing pressure index & 0.0283 & 0.0001 & 0.0001 \\
\hline Utilization & 0.0073 & 0.0001 & 0.0001 \\
\hline \multicolumn{4}{|l|}{ Grazing efficiency } \\
\hline Equation 1 & 0.0758 & 0.0001 & 0.2573 \\
\hline Equation 2 & 0.1905 & 0.0004 & 0.5972 \\
\hline Equation 3 & 0.0773 & 0.0001 & 0.3356 \\
\hline \multicolumn{4}{|l|}{ Harvest efficiency } \\
\hline Equation 1 & 0.0256 & 0.0001 & 0.0001 \\
\hline Equation 2 & 0.0560 & 0.0001 & 0.0001 \\
\hline Equation 3 & 0.0340 & 0.0001 & 0.0001 \\
\hline
\end{tabular}

stocking rates compared to the other five sites (Figs. 3D-3F). At the light stocking rate, the other five sites had similar harvest efficiencies for all three intake equations, but were different at the moderate and at the heavy stocking rates.

The main effect of stocking rate was significant for GPI, utilization, harvest efficiency, and grazing efficiency (Tables 3 and 4). Grazing pressure index at heavy stocking was 1.7 and 2.9 times greater than at moderate and light stocking rates. Utilization at heavy stocking was 1.3 and 1.6 times greater than at moderate and light stocking rates. Harvest efficiency for all three equations was significantly different between heavy, moderate, and light stocking rates (Table 4). When harvest efficiency was averaged across equations, heavy stocking $(38 \%)$ resulted in 1.6 and 2.7 times greater harvest efficiency than moderate $(24 \%)$ and light stocking $(14 \%)$, respectively. Grazing efficiency differed $(P<0.05)$ between stocking rates for the Allison et al. (1982) constant intake estimate and the Poppi (1996) equation (Table 4). The Redmon et al. (1995) equation resulted in greater harvest efficiency at heavy and moderate rates than at light stocking rates (Table 4). Averaged over intake methods, grazing efficiency at heavy stocking $(61 \%)$ was 1.2 and 1.6 times greater than at moderate $(49 \%)$ and light $(39 \%)$ stocking rates.

The main effect of site was significant for GPI, utilization, and harvest efficiency for the Allison et al. (1982) constant intake estimate and Poppi (1996) equation (Tables 3 and 5). However, grazing efficiencies were similar between sites for each of the intake methods (Tables 3 and 5). Grazing pressure indices were greater at Woodward than the other sites. Utilization was least at Streeter compared to the other sites. Woodward also had greater harvest efficiencies when calculated using the Allison et al. (1982) constant intake estimate or Poppi (1996) equations compared to the other sites (Table 5).

\section{Regression Analysis}

The mathematical relationship between GPI and harvest efficiency was a linear function regardless of the method used
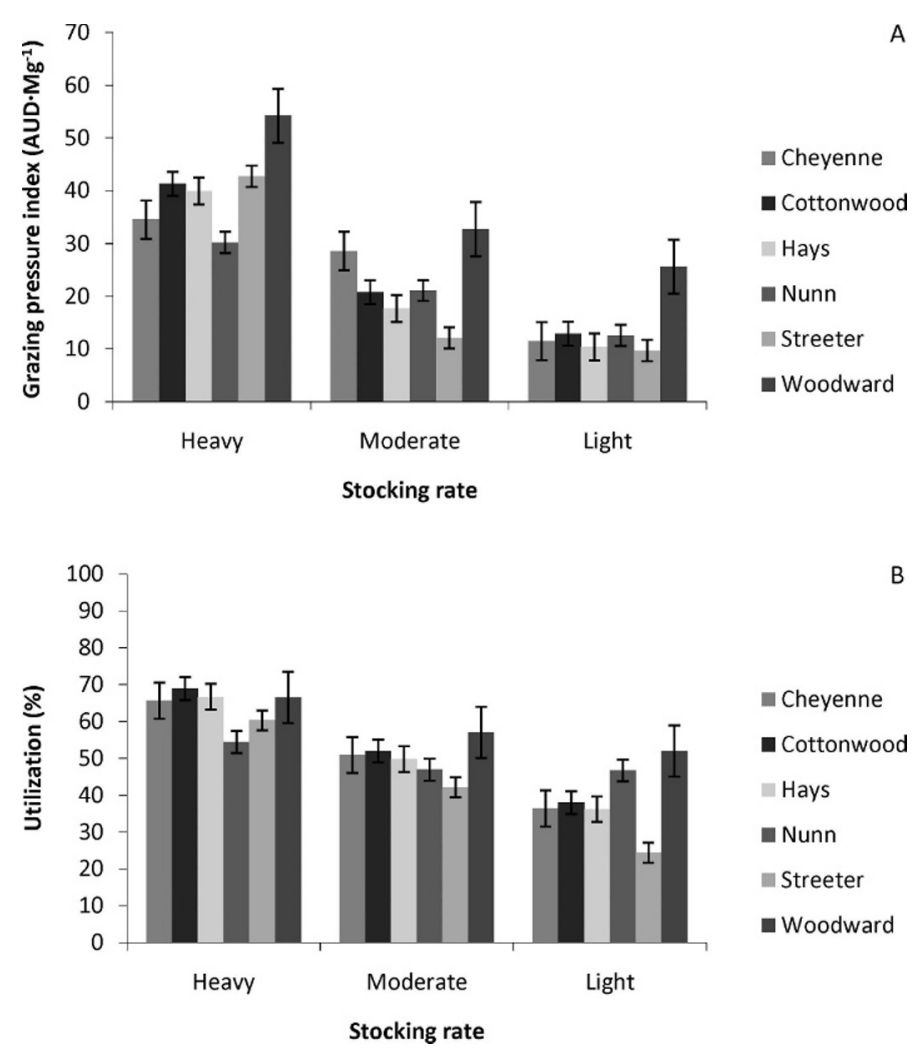

Figure 2. A, Grazing pressure index and B, utilization means and standard errors for three stocking rates and six sites in the North American Great Plains. AUD indicates animal unit days.

to estimate daily forage intake (Fig. 4). The relationship between GPI and utilization was best explained by a quadratic function (Fig. 5). Minimum and maximum utilizations were $23 \%$ and $69 \%$, respectively. Relationships between GPI and grazing efficiency were best explained by linear equations whether intake was considered constant or adjusted for different levels of cumulative grazing pressures (Fig. 6). Estimates of grazing efficiency ranged from $25 \%$ to $105 \%$ (Fig. 6A) for the constant intake estimate of Allison et al. (1982), whereas estimates of grazing efficiency ranged from $32 \%$ to $100 \%$ (Fig. $6 \mathrm{~B}$ ) for intakes adjusted for cumulative grazing pressure by Redmon et al. (1995). Grazing efficiency ranged from 32\% to $118 \%$ using the intake model of Poppi (1996; Fig. 6C). Grazing efficiency estimates $>100 \%$ at high GPI could be a result of overestimating intake or under-estimating herbage disappearance. The relationship between GPI, ADG, and gain, after locations were adjusted for their y-intercept, resulted in significant linear equations that explained $96 \%$ of the variation, respectively (Figs. 7A and 7B). Grazing pressure index and ADG had a pooled slope $\left(-0.0044 \pm 0.001 \mathrm{~kg} \cdot \mathrm{d}^{-1}\right)$. The baseline $y$-intercept used for Streeter was $0.66 \pm 0.03 \mathrm{~kg} \cdot \mathrm{d}^{-1}$. Hays was not significantly different from Streeter $(P=0.88)$. Y-intercepts for Cheyenne $\left(1.09 \pm 0.03 \mathrm{~kg} \cdot \mathrm{d}^{-1}\right)$ and Nunn $\left(0.88 \pm 0.03 \mathrm{~kg} \cdot \mathrm{d}^{-1}\right)$ were significantly different from Streeter $(P<0.001)$. The pooled slope for gain was $1.30 \pm 0.15 \mathrm{~kg} \cdot \mathrm{ha}^{-1}$. The baseline y-intercept used for Streeter was $31.4 \pm 4.13 \mathrm{~kg} \cdot \mathrm{ha}^{-1}$. Hays was not significantly different from Streeter $(P=0.11)$. Y-intercepts for Cheyenne $\left(5.32 \pm 3.99 \mathrm{~kg} \cdot \mathrm{ha}^{-1}\right)$ and Nunn $\left(-6.90 \pm 4.09 \mathrm{~kg} \cdot \mathrm{ha}^{-1}\right)$ were significantly different from Steeter $(P<0.001)$. 

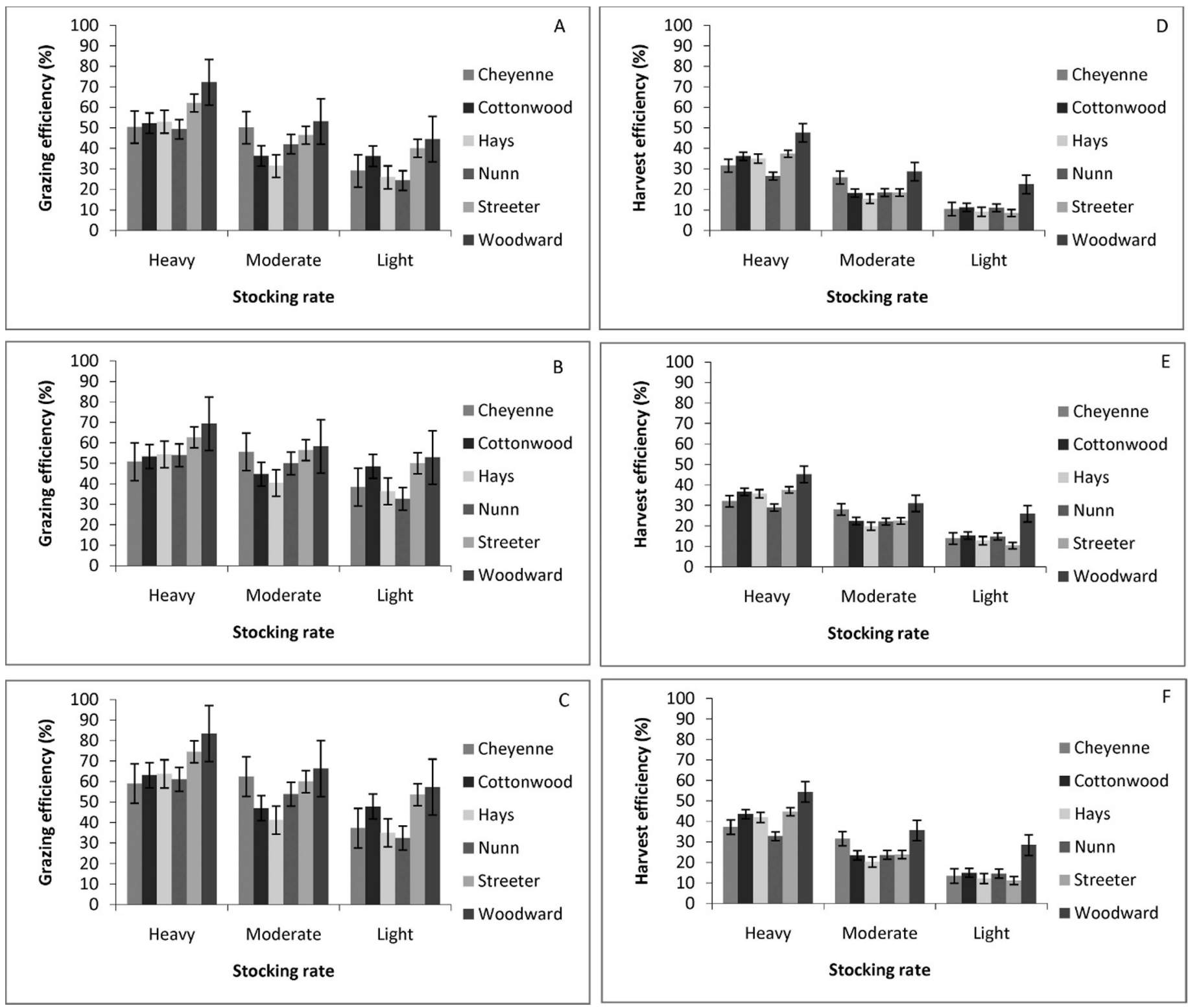

Figure 3. Grazing and harvest efficiency means and standard errors for stocking rates and sites estimated using a constant intake from (A, D) Allison et al. (1982), (B, E) intake modeled after Redmon et al. (1995), and (C, F) intake modeled after Poppi (1996).

Table 4. Grazing pressure index (GPI), utilization (U), harvest efficiency, and grazing efficiency from heavy, moderate, and light stocking rates conducted at six sites in the North American Great Plains.

\begin{tabular}{|c|c|c|c|c|c|c|c|c|}
\hline \multirow[b]{2}{*}{ Stocking rate } & \multirow[b]{2}{*}{$\operatorname{GPI}\left(\bar{x}\left[\mathrm{SE}^{1}\right]\right)$} & \multirow[b]{2}{*}{$\mathrm{U}(\overline{\mathrm{x}}[\mathrm{SE}])$} & \multicolumn{3}{|c|}{ Harvest efficiency } & \multicolumn{3}{|c|}{ Grazing efficiency } \\
\hline & & & Eq. $1^{2}(\bar{x}[S E])$ & Eq. 2 (र [SE]) & Eq. $3(\bar{x}[S E])$ & Eq. 1 ( $\bar{x}[S E])$ & Eq. 2 (र $[S E])$ & Eq. $3(\bar{x}[S E])$ \\
\hline & $\mathrm{AUD} \cdot \mathrm{Mg}^{-1}$ & 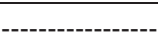 & - & - & --- \% --- & - & - & - \\
\hline Heavy & $40 c^{3}(1.3)$ & $64 \mathrm{a}(1.7)$ & 36 a (1.1) & $37 \mathrm{a}(1.0)$ & $42 \mathrm{a}(1.2)$ & $57 \mathrm{a}(2.8)$ & 59 a (3.3) & 67 a (3.0) \\
\hline Moderate & $24 \mathrm{~b}(1.3)$ & 50 b (1.7) & $21 \mathrm{~b}(1.1)$ & 24 b (1.0) & $26 \mathrm{~b}(1.2)$ & $43 \mathrm{~b}(2.8)$ & 51 a (3.3) & 54 b (3.0) \\
\hline Light & 14 a (1.3) & $39 \mathrm{c}(1.7)$ & 12 c (1.1) & 15 c (1.0) & 16 c (1.2) & 33 c (2.8) & $41 \mathrm{~b}(3.3)$ & 42 c (3.0) \\
\hline$P$ value & $<0.01$ & $<0.01$ & $<0.01$ & $<0.01$ & $<0.01$ & $<0.01$ & $<0.01$ & $<0.01$ \\
\hline
\end{tabular}

${ }^{1} \mathrm{SE}$ indicates standard error of the mean; AUD, animal unit days.

${ }^{2}$ Intake equations: Eq. 1 is a constant intake of $8.75 \mathrm{~kg} \cdot$ AUD $^{-1}$ after Allison et al. (1982), Eq. 2 is adjusted for forage allowance using an equation described by Redmon et al. (1995), and Eq. 3 is $11.8 \mathrm{~kg} \cdot$ AUD $^{-1}$ adjusted for forage allowance using an equation described by Poppi (1996).

${ }^{3}$ Means followed by different letters within a column are significantly different $(P<0.05)$. 
Table 5. Grazing pressure (GPI), utilization (U), harvest efficiency, and grazing efficiency from six sites in the North American Great Plains.

\begin{tabular}{|c|c|c|c|c|c|c|c|c|}
\hline \multirow[b]{2}{*}{ Location } & \multirow[b]{2}{*}{$\operatorname{GPI}\left(\overline{\mathrm{x}}\left[\mathrm{SE}^{1}\right]\right)$} & \multirow[b]{2}{*}{$U(\bar{x}[S E])$} & \multicolumn{3}{|c|}{ Harvest efficiency } & \multicolumn{3}{|c|}{ Grazing efficiency } \\
\hline & & & Eq. $1^{2}(\bar{x}[S E])$ & Eq. 2 (र [SE]) & Eq. 3 (र [SE]) & Eq. 1 ( $\bar{x}[S E])$ & Eq. 2 ( $\bar{x}[S E])$ & Eq. 3 ( $\bar{x}[S E])$ \\
\hline & $\mathrm{AUD} \cdot \mathrm{Mg}^{-1}$ & & & & \% - & -----. & $x^{2}=x^{2}$ & - \\
\hline Cheyenne, WY & $25 b^{3}(2.9)$ & 51 a (3.9) & $23 \mathrm{~b}(2.5)$ & 25 a (2.4) & 27 b (2.9) & 43 a (6.5) & 48 a (7.5) & 53 a (8.0) \\
\hline Cottonwood, SD & $25 \mathrm{~b}(1.8)$ & 53 a (2.5) & $22 \mathrm{~b}(1.6)$ & 25 a (1.5) & 27 b (1.8) & $42 \mathrm{a}(4.1)$ & 49 a (4.7) & 53 a $(5.1)$ \\
\hline Hays, KS & $23 \mathrm{~b}(1.9)$ & 51 a (2.5) & $20 \mathrm{~b}(1.6)$ & $23 \mathrm{a}(1.5)$ & $25 \mathrm{~b}(1.9)$ & 37 a (4.2) & 44 a (4.8) & $47 \mathrm{a}(5.1)$ \\
\hline Nunn, CO & $21 \mathrm{~b}(1.8)$ & 49 a (2.5) & 19 b (1.5) & 22 a (1.4) & $24 \mathrm{~b}(1.8)$ & 39 a (3.9) & 46 a (4.5) & 50 a (4.9) \\
\hline Streeter, ND & $25 \mathrm{~b}(1.5)$ & $42 \mathrm{~b}(2.1)$ & 22 b (1.3) & 24 a (1.2) & 27 b (1.5) & 51 a (3.4) & 58 a (3.9) & 65 a (4.2) \\
\hline Woodward, OK & $37 \mathrm{a}(4.1)$ & 59 a (5.5) & 33 a (3.6) & 34 a (3.3) & 39 a (4.1) & 57 a (9.3) & 60 a (11.0) & 69 a (11.0) \\
\hline$P$ value & $<0.01$ & $<0.01$ & 0.02 & 0.06 & 0.03 & 0.07 & 0.19 & 0.08 \\
\hline
\end{tabular}

${ }^{1} \mathrm{SE}$ indicates standard error of the mean; AUD, animal unit days.

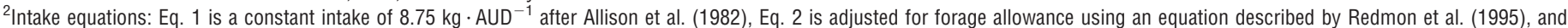
Eq. 3 is $11.8 \mathrm{~kg} \cdot \mathrm{AUD}^{-1}$ adjusted for forage allowance using an equation described by Poppi (1996).

${ }^{3}$ Means followed by different letters within a column are significantly different $(P<0.05)$.

\section{DISCUSSION}

Grazing pressure index was a useful approach to effectively compare stocking rates across the six studies conducted in the North American Great Plains. Harvest efficiency for moderate stocking rates was similar to the targeted goal of $25 \%$ (Galt et al. 2000). Of particular importance, however, is that harvest efficiency was not $25 \%$ at either the heavy or light stocking rates. Harvest efficiency was estimated to be $13 \%$ to $16 \%$ higher under heavy stocking rates and $6 \%$ to $10 \%$ lower under light stocking rates compared to moderate stocking rates. In addition, grazing efficiencies with heavy or light stocking rates were not $50 \%$. Grazing efficiency ranged from $8 \%$ to $14 \%$ higher under heavy stocking rates and $10 \%$ to $12 \%$ lower under light stocking rates compared to moderate stocking rates. Collectively, these findings demonstrate that both harvest (Fig. 4) and grazing (Fig. 6) efficiencies scale linearly with changes in GPI.

The linear equation that describes the relationship between GPI and harvest efficiency (Fig. 4) in conjunction with the quadratic response of utilization to GPI (Fig. 5) are fundamental to understanding why grazing efficiency changes over a range of GPI (Fig. 6). At high GPI, a greater proportion of the total forage available is demanded by livestock according to their daily intake, even if intake is restricted because of declining forage quantity or quality (Combellas and Hodgson

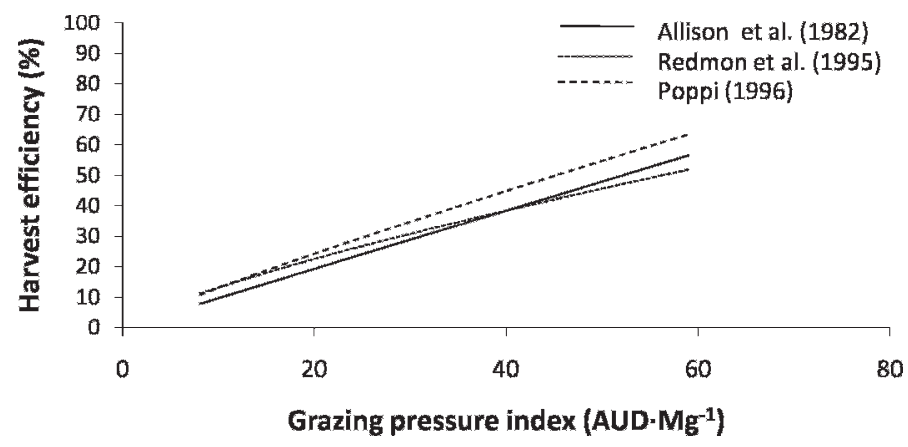

Figure 4. Relationship between grazing pressure index and harvest efficiency estimated using a constant intake from Allison et al. (1982): $\mathrm{y}=0.97 \mathrm{x}-0.19\left(R^{2}=0.99\right)$, intake modeled after Redmon et al. (1995): $y=0.79 x+6.23\left(R^{2}=0.98\right)$, and intake modeled after Poppi (1996): $\mathrm{y}=1.02 \mathrm{x}+3.69\left(R^{2}=0.99\right)$. AUD indicates animal unit days.
1979; Penning et al. 1991; Redmon et al. 1995; Poppi 1996). The relationship between GPI and utilization was quadratic; thus, utilization levels off at higher grazing pressure. This can happen only if grazing efficiency increases as GPI increases (Fig. 8A). If the response curve of utilization had been linear, grazing efficiency would not have increased.

Because grazing efficiency is a calculation of intake and utilization, the explanation for changes in grazing efficiency across different values of GPI is best understood by examining the mechanisms that affect utilization. Utilization is essentially the vegetation biomass that disappears from the plant community, not only due to grazing by livestock, but also to weathering, trampling, fouling, senescence, and intake or clipping by insects or wildlife (Fig. 8A). Intake or destruction from other herbivores has not been well-documented in grazing studies except in certain circumstances when wildlife such as prairie dogs (Cynomys ludovicianus) or grasshoppers (Aulocara elliotti) are known to be highly competitive (Hewitt et al. 1976; Stoltenberg 2004). Losses due to herbage fouling and trampling have been observed to be greater under moderate and heavy stocking $(<5 \%)$ compared to light stocking $(1 \%$; Quinn and Hervey 1970). Therefore, we would expect forage disappearance caused by trampling to be very minimal unless stocking density is excessive. Thus, the most likely explanation for improved grazing efficiency is a reduction in the amount of

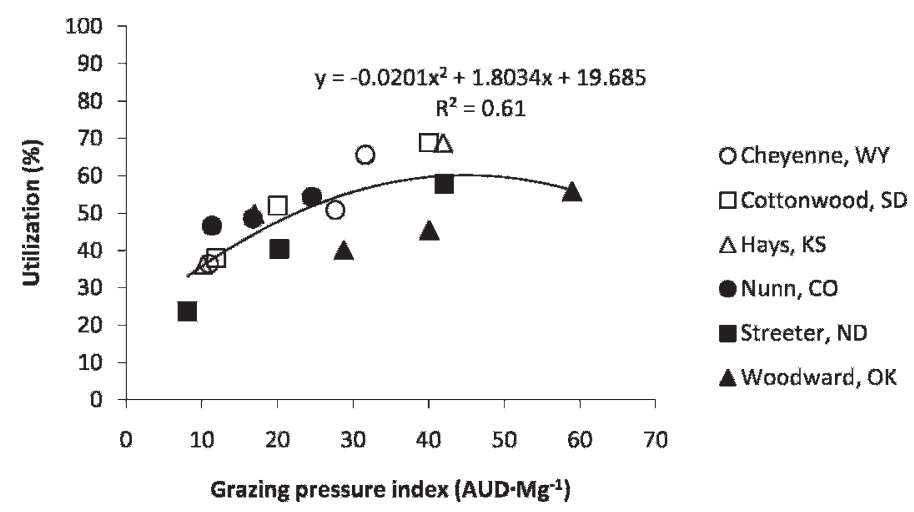

Figure 5. Relationship between grazing pressure index and utilization from six stocking rate studies in the North American Great Plains. AUD indicates animal unit days. 

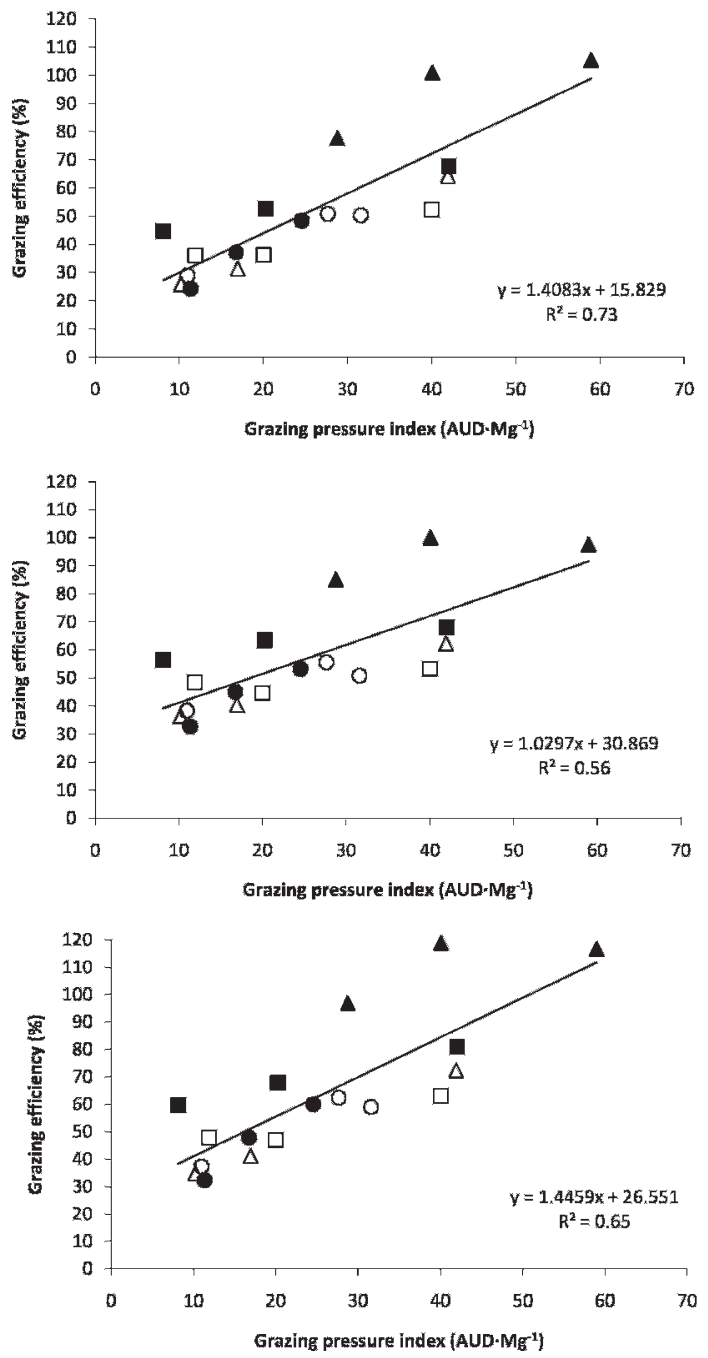

OCheyenne, WY $\square$ Cottonwood, 50 $\triangle$ Hays, K5

- Nunn, $\mathrm{CO}$ - Streeter, ND $\triangle$ Woodward, OK OCheyenne, WY 口Cottonwood, SD $\triangle$ Hays, KS - Nunn, CO - streeter, ND $\Delta$ Woodward, OK c

oCheyenne, WY $\square$ Cottonwood, SD $\triangle$ Hays, KS - Nunn, CO - Streeter, ND $\Delta$ Woodward, OK

Figure 6. Relationship between grazing pressure index and grazing efficiency estimated using a constant intake after A, Allison et al. (1982); B, intake modeled after Redmon et al. (1995); and C, and intake modeled after Poppi (1996). AUD indicates animal unit days.

senescent and weathered vegetation. Penning et al. (1991) argued that increased grazing intensity would result in a greater percentage of leaves harvested (Bircham and Hodgson 1983; Parsons et al. 1983), which would reduce the leaf area index (LAI), photosynthesis, and the rate of gross tissue production. Penning et al. (1991) showed that perennial ryegrass (Lolium perenne L.) pastures grazed to maintain a 1.0 LAI had $27 \%$ less dead stem mass and $45 \%$ more vegetative tillers than swards of 2.0 LAI. Others also documented that grazing efficiencies are greater on swards maintained at lower sward canopy height or LAI and attributed this phenomenon to lesser amounts of accumulated senescent vegetation in the shorter swards (Parsons et al. 1983; Heitschmidt et al. 1989; Mazzanti and Lemaire 1994; Nakatsuji et al. 2006; Agnusdei et al. 2007).

The linear relationship between GPI and ADG (Fig. 7) was similar to previous findings (Bement 1969; Hart 1972; Hart et al. 1988; Hart and Ashby 1998). The linear coefficient from our study $(-0.0044)$ was in the range of values reported by Hart et al. (1988) and Hart and Ashby (1988). The goodness of fit from our pooled data set (across Cheyenne, Hays, Nunn, and Streeter study sites), after adjustments in y-intercepts were

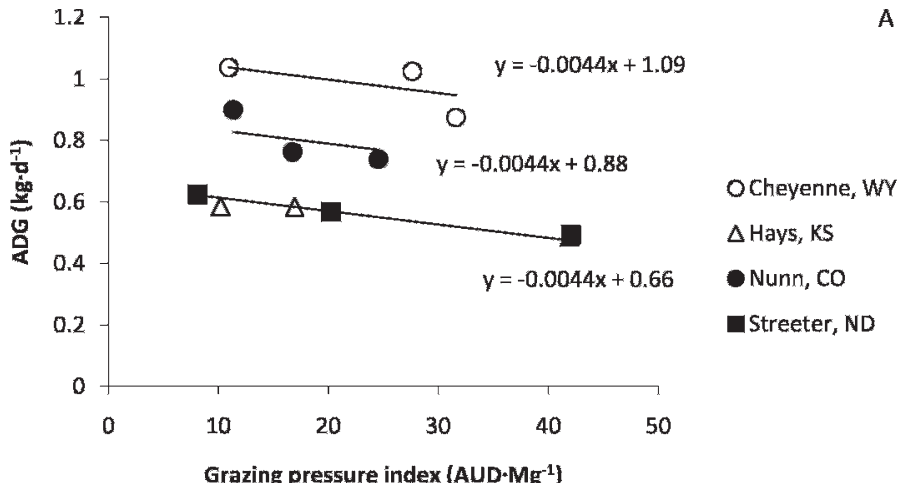

B

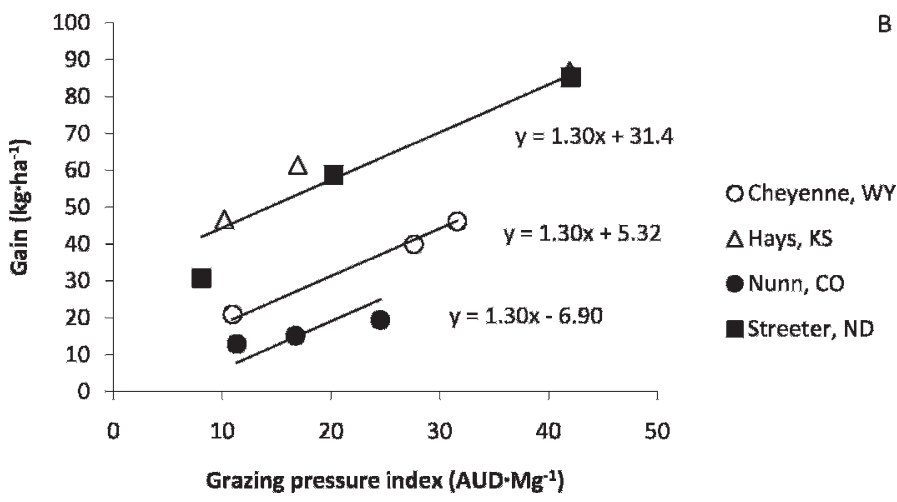

Figure 7. Relationships between grazing pressure index and $\mathbf{A}$, average daily gain (ADG) of yearling cattle and $\mathbf{B}$, gain of yearling cattle per hectare from four sites using a pooled slope but adjusted for different $y$ intercepts were significant $\left(R^{2}=0.96 ; P<0.01\right)$ for both $\mathrm{ADG}$ and gain. AUD indicates animal unit days.

made, was greater than from a single site (Hart et al. 1988; Hart and Ashby 1998) or several sites with similar plant communities (Hart 1972). Adjustments in y-intercepts for these pooled data set were necessary for several reasons. The response in ADG from the four study sites that used yearling cattle would have been influenced by different genetics from within- and amongbreed variation. Because the data from some of the locations were collected during the late 1950s and early 1960s as compared to the 1990s, cattle might have had different selection pressure applied to them for various growth traits. Lastly, forage quality might have been different at each study site. Harlan (1958) observed that the shift in plant community from taller grasses to mid- and short grasses at heavier stocking rates at the Woodward site resulted in high forage quality, which helped offset any losses in animal performance. Powell et al. (1982) observed greater digestibility of forages and greater dry matter intake from steers grazing lower range condition than higher range condition in the Nebraska Sandhills. Crude protein was greater in the diets of steers grazing high range condition compared to low range condition, and thus ADG was similar between the two pastures (Powell et al. 1982). Heitschmidt et al. (1989) also determined that greater forage quality occurred in heavily stocked pastures compared to moderately stocked pastures because of reduced standing dead vegetation. A review of the literature by Allison (1985) supports these findings.

The relationship between animal gain $\cdot \mathrm{ha}^{-1}$ and GPI has been shown to be linear to a point of heavy stocking and 

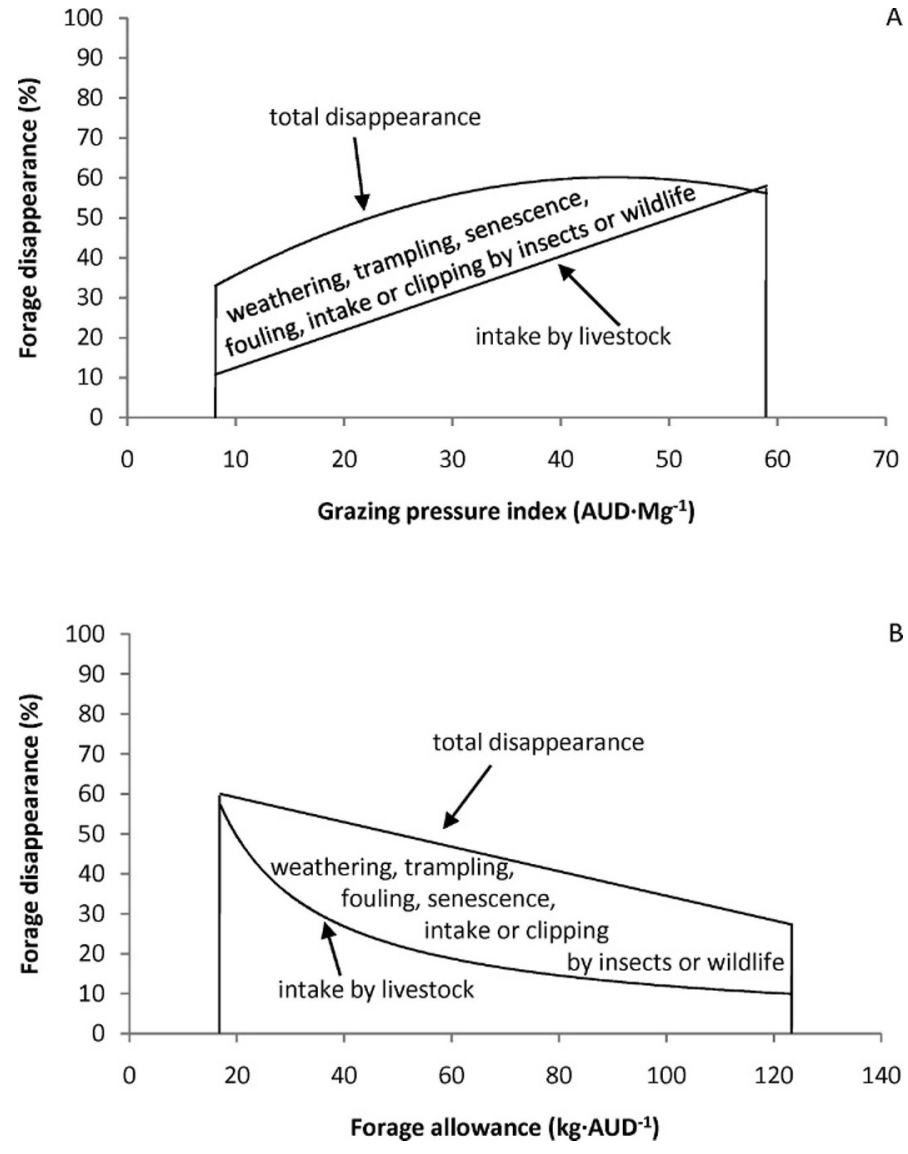

Figure 8. Forage intake by livestock (average of the three harvest efficiency models) and total disappearance in relation to $\mathbf{A}$, grazing pressure index and $\mathbf{B}$, forage allowance. Because forage intake by livestock and total disappearance varies disproportionately over different levels of grazing pressure index or forage allowance, grazing efficiency increases from low grazing pressure to high grazing pressure or high forage allowance to low forage allowance. AUD indicates animal unit days.

curvilinear beyond heavy stocking (Harlan 1958; Hart et al. 1988). Because our pooled data set did not include GPI $>50$ AUD $\cdot \mathrm{Mg}^{-1}$, we did not see the curvilinear response (Fig. 7). Hart et al. (1988) described a theoretical maximum gain $\cdot \mathrm{ha}^{-1}$ would occur at 105.5 steer-days $\cdot \mathrm{ha}^{-1}\left(63 \mathrm{AUD} \cdot \mathrm{Mg}^{-1}\right)$ and the optimum stocking rate, giving the greatest return $\cdot \mathrm{ha}^{-1}$, would occur at 57.7 steer-days $\cdot \mathrm{ha}^{-1}\left(34 \mathrm{AUD} \cdot \mathrm{Mg}^{-1}\right)$. Because cumulative grazing pressure averaged $40 \mathrm{AUD} \cdot \mathrm{Mg}^{-1}$ for heavy and $24 \mathrm{AUD} \cdot \mathrm{Mg}^{-1}$ for moderate stocking, optimum return of beef production on Great Plains rangelands should occur between moderate and heavy stocking.

Others have proposed using forage allowance to standardize stocking rate studies (Hart 1972; Sollenberger et al. 2005). Hart (1972) made a significant discovery that grazing pressure (inverse of forage allowance) resulted in a linear function that gave better fits for ADG and gain per unit area compared to the rectangular hyperbola when regressed against forage allowance. This also proved to be true with our data set. When intake by livestock was plotted against forage allowance, it resulted in a decreasing exponential function (Fig 8B). However, when intake of livestock was plotted against GPI, the function was linear (Fig. 8A). Hart (1972) stated that conceptually "it is easier to visualize the relationship" between forage allowance and ADG or gain per unit land area. For example, if we assume forage allowance is $36 \mathrm{~kg} \cdot \mathrm{AUD}^{-1}$ and intake is $12 \mathrm{~kg} \cdot \mathrm{AUD}^{-1}$, then forage allowance is simply three times intake. If GPI is $36 \mathrm{AUD} \cdot \mathrm{Mg}^{-1}$, it is less clear as to what it means on a per animal basis. Taking the inverse of GPI and multiplying by 1000 converts it to forage allowance. In this example, a GPI of $36 \mathrm{AUD} \cdot \mathrm{Mg}^{-1}$ is equivalent to a forage allowance of $28 \mathrm{~kg} \cdot \mathrm{AUD}^{-1}$ or approximately 2.3 times intake. We agree with Hart (1972) that conceptually forage allowance is easier to grasp because it is a multiple of animal intake; however, mathematically it is simpler to express these relationships as linear functions of GPI. We propose that grazing management scientists should be analyzing and reporting their results as GPI instead of forage allowance.

Relationships presented here, describing harvest and grazing efficiencies across grazing pressures from six stocking rate studies conducted in the North American Great Plains, reaffirm assumptions about moderate stocking regarding grazing and harvest efficiencies. Novel here, however, is that grazing and harvest efficiency scale linearly with GPI so that grazing and harvest efficiencies increase as grazing pressure increases. Use of GPI to "standardize" stocking rates across rangeland ecosystems in the North American Great Plains should improve communications among scientists, management agencies, land managers, and the public regarding this primary rangeland management practice for production and conservation goals on these lands. Quantifying grazing pressure removes ambiguity associated with qualitative terms of heavy, moderate, or light stocking rates. Average GPI for heavy, moderate, and light stocking rates across the study sites of 40, 24, and $14 \mathrm{AUD} \cdot \mathrm{Mg}^{-1}$, respectively, and the resulting harvest efficiency values of $42 \%, 26 \%$, and $16 \%$ for heavy, moderate, and light stocking rates provide context for land managers regarding decision making on these rangeland ecosystems.

\section{LITERATURE CITED}

Agnusdei, M. G., S. G. Assuero, R. C. Fernandez Grecco, J. J. Cordero, and V. H. BuRGHI. 2007. Influence of sward conditions on leaf tissue turnover in tall fescue and tall wheatgrass swards under continuous grazing. Grass and Forage Science 62:55-65.

Alusson, C. D. 1985. Factors affecting forage intake by range ruminants: a review. Journal of Range Management 38:305-311.

Allison, C. D., M. M. Kothmann, and L. R. Rittenhouse. 1982. Efficiency of forage harvest by grazing cattle. Journal of Range Management 35:351-354.

Bement, R. E. 1969. A stocking rate guide for beef production on blue-grama range. Journal of Range Management 22:83-86.

Bircham, J. S., And J. Hodgson. 1983. The influence of sward condition rates on herbage growth and senescence in mixed swards under continuous stocking management. Grass and Forage Science 38:323-331.

Combellas, J., AND J. Hodgson. 1979. Herbage intake and milk production by grazing dairy cows. 1. The effects of variation in herbage mass and daily herbage allowance in a short-term trial. Grass and Forage Science 34:209-214.

Conniffe, D., D. Browne, and M. Walshe. 1970. Experimental design for grazing trials. Journal of Agricultural Science 64:339-342.

Derner, J. D., and R. H. Hart. 2007. Grazing-induced modifications to peak standing crop in northern mixed-grass prairie. Rangeland Ecology and Management 60:270-276. 
Derner, J. D., W. K. Lauenroth, P. Stapp, and D. J. Augustine. 2009. Livestock as ecosystem engineers for grassland bird habitat in the western Great Plains of North America. Rangeland Ecology and Management 62:111-118.

DyksterhuIs, E. J. 1949. Condition and management of range land based on quantitative ecology. Journal of Range Management 2:104-115.

Galt, D., F. Molinar, J. Navarro, J. Joseph, and J. Holechek. 2000. Grazing capacity and stocking rate. Rangelands 22:7-11.

GilleEN, R. L., AND P. L. Sims. 2002. Stocking rate and cow-calf production on sand sagebrush rangeland. Journal of Range Management 55:542-550.

Gillen, R. L., AND P. L. Sims. 2004. Stocking rate, precipitation, and herbage production on sand sagebrush-grassland. Journal of Range Management $57: 148-152$

HarLan, J. R. 1958. Generalized curves for gain per head and gain per acre in rates of grazing studies. Journal of Range Management 11:141-147.

HART, R. H. 1972. Forage yield, stocking rate, and beef gains on pasture. Herbage Abstracts 42:345-353.

HaRt, R. H., and M. M. Ashby. 1998. Grazing intensities, vegetation, and heifer gains: 55 years on shortgrass. Journal of Range Management 51:392-398.

Hart, R. H., M. J. Samuel, P. S. TeSt, And M. A. Smith. 1988. Cattle, vegetation, and economic responses to grazing systems and grazing pressure. Journal of Range Management 41:282-286.

Heitschmidt, R. K., S. L. Dowhower, W. E. Pinchak, and S. K. Canon. 1989. Effect of stocking rate on quantity and quality of available forage in a southern mixed grass prairie. Journal of Range Management 42:468-473.

Hewitt, G. B., W. H. Burleson, and J. A. Onsager. 1976. Forage losses caused by the grasshopper Aulocara elliotti on shortgrass rangeland. Journal of Range Management 29:376-380.

Holechek, J. L., R. D. Pieper, And C. H. Herbel. 2004. Range management: principles and practices. 5th ed. Upper Saddle River, NJ, USA: Pearson Prentice Hall. $607 \mathrm{p}$.

KLIPPle, G. E., And R. E. Bement. 1961. Light grazing-is it economically feasible as a range-improvement practice. Journal of Range Management 14:57-62.

Launchbaugh, J. L. 1967. Vegetation relationships associated with intensity of summer grazing on a clay upland range site in the Kansas 20- to 24-inch precipitation zone. Kansas Agricultural Experiment Station Technical Bulletin 154:1-24.

LitTell, R. C., R. J. Freund, and P. C. Spector. 1991. SAS system for linear models. 3rd ed. Cary, NC, USA: SAS Institute. 329 p.

Mazzanti, A., and G. Lemalre. 1994. Effect of nitrogen fertilization on herbage production of tall fescue swards continuously grazed by sheep. 2 . Consumption and efficiency of herbage utilization. Grass and Forage Science 49:352-359.

Milchunas, D. G., O. E. Sala, and W. K. Lauenroth. 1988. A generalized model of the effects of grazing by large herbivores on grassland community structure. American Midland Naturalist 132:87-106.

NakatsuJi, H., Y. Nishimichi, M. Yayota, M. Takahashi, K. Ueda, S. Kondo, and M. OKubo. 2006. Effects of grass height and milk production under rotational grazing by lactating dairy cows. Grassland Science 52:175-180.
National Research Council. 1987. Predicting feed intake of food-producing animals. Washington, DC, USA: National Academy Press. 85 p.

PARKER, K. W. 1954. Application of ecology in the determination of range condition and trend. Journal of Range Management 7:14-23.

Parsons, A. J., E. L. Leafe, B. Collett, P. D. Penning, and J. Lewis. 1983. The physiology of grass production under grazing. II. Photosynthesis, crop growth and animal intake of continuously-grazed swards. Journal of Applied Ecology $20: 127-139$.

Patton, B. D., X. Dong, P. E. Nyren, and A. Nyren. 2007. Effects of grazing intensity, precipitation, and temperature on forage production. Rangeland Ecology and Management 60:656-665.

Penning, P. D., A. J. Parsons, R. J. Orr, and T. T. Treacher. 1991. Intake and behavior responses by sheep to changes in sward characteristics under continuous stocking. Grass and Forage Science 46:15-28.

Poppl, D. P. 1996. Predictions of food intake in ruminants from analyses of food composition. Australian Journal of Agriculture Research 47:489-504.

Powell, D. J., D. C. Clanton, and T. J. Nichols. 1982. Effect of range condition on the diet and performance of steers grazing native Sandhills range in Nebraska. Journal of Range Management 35:96-99.

Quinn, J. A., And D. F. Hervey. 1970. Trampling losses and travel by cattle on Sandhills range. Journal of Range Management 23:50-55.

Redmon, L. A., F. T. McCollum III, G. W. Horn, M. D. Cravey, S. A. Gunter, P. A. Beck, J. M. Mieres, and R. San Julian. 1995. Forage intake by beef steers grazing winter wheat with varied herbage allowances. Journal of Range Management 48:198-201.

RIEWE, M. E. 1961. Use of the relationship of stocking rate to gain of cattle in an experimental design for grazing trials. Agronomy Journal 53:309-313.

SAS Institute Inc. 2006. SAS OnlineDoc ${ }^{\circledR}$ 9.1.3. Cary, NC, USA: SAS Institute, Inc.

Smart, A. J., B. H. Dunn, P. S. Johnson, L. Xu, and R. N. Gates. 2007. Using weather data to explain herbage yield on three Great Plains plant communities. Rangeland Ecology and Management 60:146-153.

Sollenberger, L. E., J. E. Moore, V. G. Allen, and C. G. S. Pedreira. 2005. Reporting forage allowance in grazing experiments. Crop Science 45:896-900.

[SRM] Society for Range Management. 1998. Glossary of terms used in range management. 4th ed. Denver, CO, USA: Society for Range Management. $32 \mathrm{p}$.

Steel, R. G. D., and J. H. Torrie. 1980. Principles and procedures of statistics: a biometrical approach. 2nd ed. New York, NY, USA: McGrawHill. $633 \mathrm{p}$.

Stoltenberg, M. B. 2004. Effects of prairie dogs on plant community composition and vegetation disappearance in mixed-grass prairie [thesis]. Brookings, SD, USA: South Dakota State University. $72 p$.

Stuth, J. W., D. R. Kirby, and R. E. Chmielewski. 1981. Effect of herbage allowance on the efficiency of defoliation by the grazing animal. Grass and Forage Science 36:9-15.

Van Poollen, H. W., and J. R. Lacey. 1979. Herbage responses to grazing systems and stocking intensities. Journal of Range Management 32:250-253. 